\title{
Sexual Violence Against Men AND WOMEN IN WAR: A Masculinities Approach
}

\author{
Valorie K. Vojdik*
}

INTRODUCTION

Sexual violence against men during war has occurred throughout history, yet remains largely invisible. Following the mass rape of hundreds of thousands of women during armed conflicts in former Yugoslavia and Rwanda, feminist human rights advocates succeeded in persuading international tribunals to recognize sexual violence against women as a weapon of war, crime against humanity, and means of genocide. In each of these conflicts, men were also raped, castrated, and sexually assaulted, yet they are largely absent from the international jurisprudence of gender violence during war. ${ }^{1}$ Reports of rape and sexual violation of male civilians, detainees, and combatants have surfaced in over twenty-five conflicts in the past two decades alone-including Syria, Congo, the former Yugoslavia, Sudan, El Salvador, Sierra Leone, Central African Republic, Sri Lanka, Iraq, Afghanistan, and Rwanda. ${ }^{2}$ Despite its prevalence, sexual violence against men in armed conflict has remained largely hidden from view under human rights and international law and theory.

Sexual violence against male civilians and combatants is not a new or isolated aberration, but rather has occurred frequently throughout history, across cultures and places. ${ }^{3}$ Persian armies, for example, carried plates filled with the penises of soldiers of the vanquished enemy, celebrating the symbolic

* Professor of Law, University of Tennessee College of Law. I would like to thank Ann McGinley, Frank Rudy Cooper, Juliet Williams, and Matthew McGraw for their insights and comments.

1 Rosemary Grey \& Laura J. Shepherd, "Stop Rape Now?”: Masculinity, Responsibility, and Conflict-Related Sexual Violence, 16 Men \& Masculinities 115, 116 (2012) ("[W]hile some (not enough) global attention has been paid to female survivors/victims of violence, considerably less has been directed at their male counterparts. . . Male victims/survivors of sexual violence remain a marginal concern to international policy . . . ."); Sandesh Sivakumaran, Sexual Violence Against Men in Armed Conflict, 18 Eur. J. INT'L L. 253, 253-55 (2007). See also Valerie Oosterveld, The Gender Jurisprudence of the Special Court for Sierra Leone: Progress in the Revolutionary United Front Judgments, 44 CoRNELL INT'L L.J. 49, 53 (2011) (gender-based violence against men has been marginalized in international criminal jurisprudence).

2 Sandesh Sivakumaran, Lost in Translation: UN Responses to Sexual Violence Against Men and Boys in Situations of Armed Conflict, 92 Int'L Rev. Red Cross 259, 264-65, 269 (2010). See also Grey \& Shepherd, supra note 1, at 121; Oosterveld, supra note 1, at 49, 69; Lara Stemple, Male Rape and Human Rights, 60 Hastings L.J. 605, 605, 612 (2009).

3 Joshua S. Goldstein, War and Gender 357, 359, 363 (2001). 
and actual domination of the enemy. ${ }^{4}$ However, despite its prevalence throughout time and across cultures, it is vastly underreported. ${ }^{5}$ Male victims suffer great social stigma and shame, fearing social ostracism if they seek treatment for the mental and physical consequences they suffer, including loss of sexual function and infertility. ${ }^{6}$ When it has been recognized, international law has categorized the rape or sexual violation of men as 'torture' or 'mutilation' rather than defining it as rape or sexual violence. ${ }^{7}$

Like violence against women, sexual violence against men is nearly unspeakable in its brutality. The sexual violation of men has included both physical and mental abuse, including rape, castration, and forced incest or sex with other men. ${ }^{8}$ In former Yugoslavia, for example, male detainees were ordered by enemy commanders to perform oral sex upon another detainee, then to hold the detainee's mouth to silence his screams while another male detainee bit off his testicles. ${ }^{9}$ Detainees in Sri Lanka were raped anally with sticks rubbed with chilies. ${ }^{10}$ In Abu Ghraib, US military troops sexually abused Iraqi detainees, including inter alia keeping Muslim male detainees naked for several days, forcing them to masturbate themselves in front of others, arranging and photographing their naked bodies in sexually explicit positions, and sodomizing a detainee with a chemical light. ${ }^{11}$

This article uses masculinities theory to broaden and enrich the understanding of sexual violence against men-and women-during war. The silence around male sexual violence during wartime raises critical questions about male bodies, gender, and power. The growing recognition of the sexual violation of men during war provides the opportunity to broaden our understanding of the relationship between sexual violence, constructions of gender, and the negotiation of power during armed conflict.

While scholars have explored the relationship between gender, female bodies, and sexual violence against women in war, there has not been a similarly rigorous consideration of gender, male bodies, and sexual violence as a weapon of war. Early feminist activists, such as Rhonda Copelon and the Women's Caucus for Gender Justice, theorized wartime rape of women within the larger context of male violence against women. ${ }^{12}$ Recently, scholars such as

\footnotetext{
4 Sivakumaran, supra note 1 , at 265.

5 Id. at $254-55$.

6 Id. at $255,273$.

7 Id. at 256 ("If the abuse is recognized, it may not always be seen as sexual violence, for the issue is often buried under the rubric of 'abuse' or 'torture'. Often times, castration is seen as 'mutilation' and rape as 'torture', a view that becomes apparent when reading reports of non-governmental and intergovernmental organizations.").

8 Id. at 261, 264.

9 Id. at 265.

10 Stemple, supra note 2, at 613 \& n.82.

11 Maj. Gen. Antonio M. Taguba, U.S. Dep't of Def., Article 15-6 Investigation of the 800th Military Police Brigade 15-17 (2004) [hereinafter Taguba RePort], available at http://www.npr.org/iraq/2004/prison_abuse_report.pdf; Seymour M. Hersh, Torture at Abu Ghraib, New YorKer (May 10, 2004) http://www.newyorker.com/archive/2004/05/10 /040510fa_fact.

12 See Megan Gerecke, Explaining Sexual Violence in Conflict Situations: Preliminary Findings from Bosnia and Herzegovina, Rwanda and Sierra Leone 17 (Feb. 15, 2009) (unpublished manuscript), available at http://citation.allacademic.com/meta/p313164_index.
} 
Janet Halley, Lara Stemple, and others have criticized earlier feminist accounts of sexual violence as essentializing gender violence as male violence against women. ${ }^{13}$ Defining rape as male domination over women, they argue, stereotypes men as perpetrators and women as victims, rendering rape of men as abnormal and invisible. Stemple argues that this "sex-specific" approach to sexual violence forecloses a gender analysis that takes the complexities of male-on-male violence into account. Postcolonial feminist theorists have analyzed sexual violence against women within a social constructivist approach that considers the symbolic relationship between female bodies and conflicts between local, ethnic and national groups. ${ }^{14}$ This approach acknowledges that wartime rape of women is not simply a product of male sexual domination, but a means of constructing and negotiating power between competing ethnic, religious, cultural, and national collectives. ${ }^{15}$ With some notable exceptions, however, these accounts similarly ignore sexual violence against male bodies. ${ }^{16}$

html (observing that while early feminists assumed a connection between sex and gender, later feminist work claimed that gender is a preformed identity and, therefore, they expect that sexual violence may target both women and men).

13 Grey \& Shepherd, supra note 1, at 120 (criticizing feminist accounts of sexual violence in war as "sex-specific" articulations that "function[ ] to normalize 'sexual and reproductive' violences against women, while simultaneously rendering similar violences against men abnormal or 'exceptional' "); Janet Halley, Rape at Rome: Feminist Interventions in the Criminalization of Sex-Related Violence in Positive International Criminal Law, $30 \mathrm{MicH}$. J. INT'L L. 1, 60, 62 (2008); Stemple, supra note 2, at 634 ("Male rape will only be curtailed when the perception of men broadens beyond one that sees men as a monolithic perpetrator class," thus making it impossible to understand sexual violence against men). See also Bennett Capers, Real Rape Too, 99 CALIF. L. Rev. 1259, 1259-60 (2011) (arguing that "rape has been gendered for too long" and that feminist scholars have responded to one form of subordination by replacing it with another that defines rape as male dominance over women and excludes male rape victims from consideration).

14 See, e.g., Doris E. Buss, Rethinking 'Rape as a Weapon of War', 17 FEMINIST LeGAL STUD. 145, 148-49 (2009). In conflicts such as the 1971 Bengali war or the conflict in Yugoslavia, "rape narratives were deployed in different ways to construct shifting conceptions of national self-identity." Id. at 154. See also Joane Nagel, Ethnicity and Sexuality, 26 AnN. Rev. Soc. 107, 107, 109 (2000) (discussing constructivist theories of sexuality, ethnicity, and nationalism); Sherrie L. Russell-Brown, Rape as an Act of Genocide, 21 BeRKELEY J. INT'L L. 350, 351 (2003) (noting the intersectionality of genocidal rape, and arguing for the acknowledgment "that genocidal rape is in fact a crime that implicates both gender and ethnicity and to understand that certain women are being raped by certain men for particular reasons"); Cindy S. Snyder et al., On the Battleground of Women's Bodies: Mass Rape in Bosnia-Herzegovina, 21 AfFilia: J. Women \& Soc. Work 184, 193 (2006) (“[W]omen's experience of rape in war, like that of the abuse of women's human rights more generally, is always determined by the intersection of a variety of factors, such as age, race, class, religion, ethnicity, and nationality"; authors argue that the complexity of such factors needs to be explored).

15 See, e.g., Goldstein, supra note 3, at 362-63 (analyzing use of mass rape during conflict as a means of ethnic cleansing); Nayanika Mookherjee, Gendered Embodiments: Mapping the Body-Politic of the Raped Woman and the Nation in Bangladesh, 88 Feminist Rev. 36, 39 (2008) (analyzing the rape of women in Bangladesh's war for independence).

16 But see Buss, supra note 14, at 159-60; Miranda Alison, Wartime Sexual Violence: Women's Human Rights and Questions of Masculinity, 33 REv. INT'L STUD. 75, 90 (2007) (arguing that "sexual violence against men and boys is no less a gendered issue than sexual violence against women and girls"). 
Rather than erase gender or male dominance from the analysis of wartime sexual violence against men, this paper incorporates insights from masculinities theory into a dominance framework to broaden the understanding of gender, power, and sexual violence against both men and women during war. Masculinities theory explores how social norms of masculinity create, enforce, and reproduce relations of power on multiple levels — between men as individuals; between men and women; and within larger social institutions such as the military, the workplace, the nation-state, and the global political order. To fully theorize sexual violence during war requires examining the relationship between violence against male bodies, social constructions of masculinity, and the use of particular masculinities to achieve ethnic, national, and global power. ${ }^{17}$

Masculinity is not a fixed identity, but rather a social practice of gender that constructs men as masculine and heterosexual, defined in opposition to those men who are perceived as effeminate or homosexual, and women. ${ }^{18}$ "Violence is often the single most evident marker of manhood," writes Michael Kimmel. ${ }^{19}$ Wartime rape of both male and female victims functions as an actual and symbolic means of masculinized dominance between competing ethnic, national, and other collectives. As Sandesh Sivakumaran observes, wartime sexual violence against men is about masculine domination and power just as it is for women-both forms of violence involve similar constructions of masculinity and heterosexualized masculine domination. ${ }^{20}$

Focusing on men and masculinities theory leads us to understand three critical points.

First, sexualized violence against men during war is not an isolated event; it has occurred throughout history, across time, place, and culture. When it has been recognized under international law, it typically has been categorized as "torture" or "mutilation" rather than as rape or sexual violence. ${ }^{21}$ As a result, it has been normalized under international law, assumed to be a natural part of the horrors of war in which men as warriors participate, and shrouded in silence.

Second, acts of wartime sexual violence against men and women are not distinct phenomena, but are inter-related. Like the rape of women, the rape and sexual violation of men constructs and enforces actual and symbolic gendered power on several levels. Sexual violence against men in war can serve multiple functions: to maintain and enforce the established gender order; to weaken, demoralize, and destroy collectives of people; to construct ethnicity, national, and other forms of collective identity; and to both construct and resist the domi-

17 Alison makes a similar point, arguing that analysis of "wartime sexual violence" needs to examine "local hegemonic and subordinate masculinities" and their relationship to "ethnonational identity, militarism, violence, and complementary constructions of femininity." Alison, supra note 16.

18 Valorie K. Vojdik, Gender Outlaws: Challenging Masculinity in Traditionally Male Institutions, 17 BerKeley WoMen's L.J. 68, 91 (2002).

19 Michael S. Kimmel, Masculinity as Homophobia: Fear, Shame, and Silence in the Construction of Gender Identity, in Toward a New Psychology of Gender 223, 234 (Mary M. Gergen \& Sara N. Davis eds., 1997).

20 Sivakumaran, supra note 1 , at 267.

21 Id. at 256. 
nance of transnational and global actors. ${ }^{22}$ Like the rape of female victims, sexual violence against male victims functions to masculinize and empower the perpetrator/collective and feminize/conquer the victim/collective. ${ }^{23}$ Both function as gendered tools to empower particular male groups within specific social spaces.

Third, sexual violence against men (and women) is not an aberrant result of the chaos of war, but rather is part of a larger social and gender system that constructs male bodies as masculine, heterosexual, and dominant. It is but one part of a continuum of violence against male bodies that occurs throughout a range of social institutions, practices, and spaces-including the military, schools, the workplace, and prisons - and within larger systems of political and global power. ${ }^{24}$ The sexual violation of both men and women is not limited to the enemy but also occurs between members of military organizations, such as the United States military, where it functions to define warriors as male and masculine, supposedly encouraging troops to fight in war. Recent polls, for example, show that 26,000 US service members experienced unwanted sexual contact in 2012, 53 percent involved attacks on men. ${ }^{25}$ From bullying of boys in schoolyards, to the sexual assault and harassment of men in the workplace, to the sexual humiliation of Muslim Arab men by US military members in Abu Ghraib, violence against men is a means of asserting masculine domination against both men and women. Within these settings, sexual violence against men tends to be normalized, shaming its male victims and rendering the violence invisible.

Part I of this article discusses the prevalence of male-on-male sexual violence against men in war throughout history and across cultures. Part II draws upon masculinities theory to explain how wartime sexual violence against men and women are inter-related. Like sexual violence against women, sexual violence against men serves multiple functions, including as a means to valorize warriors as male and masculine, to symbolically construct the male perpetrators as masculinized men while simultaneously feminizing the male victims, and to weaken or destroy the community to which the victimized men belong. Part III broadens the analytical framework to locate male-on-male sexual violence during war within a larger continuum of masculinized violence within the military, schools, prisons, and other social institutions. Using examples from the United States, this section demonstrates the multiple ways in which society normalizes male-on-male sexual violence and renders it invisible. Masculinities theory, I argue, is a valuable lens that enables us to recognize the gendered nature of violence against men that is too often ignored by law and society.

22 See Dubravka_arkov, The Body of the Other Man: Sexual Violence and the Construction of Masculinity, Sexuality and Ethnicity in Croatian Media, in Victims, Perpetrators or Actors?: Gender, Armed Conflict and Political Violence 69, 78 (Caroline O.N. Moser \& Fiona C. Clark eds., 2001) ("[W]hen the male body is ethnic and male at the same time, the castration of a single man" represents the castration of the entire ethnic group).

23 See, e.g., Sivakumaran, supra note 1, at 268.

24 R. W. Connell, Masculinities 73, 75 (1995) (discussing the production of masculinity and gender within social institutions).

25 James Dao, In Debate Over Military Sexual Assault, Men Are Overlooked Victims, N.Y. Times, June 24, 2013, at A12. 


\section{Sexual Violence Against Men During War: Prevalent YET INVISIBLE}

\section{A. Nature and Extent of Wartime Male Sexual Violence}

Sexual violence against men has occurred throughout time and place. The castration and penile amputation of male prisoners and enemies has been documented in conflicts in Ancient Persia and Ancient Greece, as well as by Chinese, Amalekite, Egyptian, and Norse armies. ${ }^{26}$ Phallic violence, both actual and symbolic, served to triumph victory of an armed group over the other. In some cultures, male corpses of enemy troops were mutilated with spears through the anus to simulate male rape and to symbolize defeat. ${ }^{27}$ Anal rape of male captives likewise occurred throughout the ancient world. ${ }^{28}$ Male sexual violence is present in Biblical accounts that proclaim that, "David took his men with him and went out and killed two hundred Philistines and brought back their foreskins." 29

During the last two decades, sexual violence against men has been documented in at least twenty-five armed conflicts throughout the world, including the Democratic Republic of Congo, Iraq, Sri Lanka, Chechnya, the Central African Republic, Iran, Kenya, the former Yugoslavia, Rwanda, and Uganda. ${ }^{30}$ During the armed conflict in the former Yugoslavia, more than 50 percent of male detainees experienced sexual torture, including 80 percent of men at a concentration camp in Sarajevo. ${ }^{31}$ In El Salvador, 76 percent of male political detainees experienced sexual torture and 21 percent of Sri Lankan men treated at a London treatment center for torture reported sexual abuse during detention. ${ }^{32}$ In Liberia, 32.6 percent of male combatants experienced sexual violence. ${ }^{33}$ In the Democratic Republic of Congo, reported acts of sexual violence committed against men and boys include anal rape and forced sexual slavery. ${ }^{34}$

There is no generally accepted definition of male sexual violence during war. ${ }^{35}$ The International Criminal Court ("ICC") defines sexual violence broadly to encompass the commission of "an act of a sexual nature" committed "by force, or by threat of force or coercion, such as that caused by fear of

26 Goldstein, supra note 3, at 357. See also Sivakumaran, supra note 1, at 257; Hilmi M. Zawati, Impunity or Immunity: Wartime Male Rape and Sexual Torture as a Crime Against Humanity, 17 ToRTURe 27, 34 (2007).

27 Goldstein, supra note 3 , at 358. Goldstein argues that the symbolic castration of the enemy continues today. $I d$.

28 Id. at 359.

291 Samuel 18:27 (New International Version).

30 Sivakumaran, supra note 2, at 264-65. See also Monica Adhiambo Onyango \& Karen Hampanda, Social Constructions of Masculinity and Male Survivors of Wartime Sexual Violence: An Analytical Review, 23 Int'l J. Sexual Health 237, 237-39 (2011); Stemple, supra note 2, at 612; Zawati, supra note 26, at 34-35.

31 Onyango \& Hampanda, supra note 30, at 238-39.

32 Will Storr, The Rape of Men: The Darkest Secret of War, OBSERver, July 16, 2011, at 36.

33 Sandesh Sivakumaran, Why the World Must Stop Ignoring Male Victims of Wartime Sexual Violence, CNN OpINION (Mar. 13, 2013, 11:44 AM), http://www.cnn.com/2013/03/13 /opinion/male-victims-sexual-violence/.

${ }_{34}$ Arche d'Alliance, A Weapon of War: Sexual Violence in South Kivu, DRC, PAMBazuka NEws (June 10, 2004), http://www.pambazuka.org/en/category/features/22523.

35 Sivakumaran, supra note 1 , at 261. 
violence, duress, detention, psychological oppression or abuse of power . . . or by taking advantage of a coercive environment or such person's . . . incapacity to give genuine consent." 36 The Rome Statute expressly lists specific crimes of sexual violence that constitute crimes against humanity including "[r]ape, sexual slavery, enforced prostitution, forced pregnancy, enforced sterilization, or any other form of sexual violence of comparable gravity." ${ }^{37}$ Written in genderneutral terms, the statute encompasses sexual violence against men during conflict.

Sexual violence against men in conflict is a broad category that includes different forms of physical and mental abuse. ${ }^{38}$ It is recognized to include rape, both oral and anal; castration and/or sterilization; genital violence, including beatings and electric shocks aimed at the penis or testicles; forced incest; forced masturbation; forced nudity, often accompanied by threats or humiliation; and sexual slavery. ${ }^{39}$ Women as well as men have been perpetrators of male sexual abuse. In Sierra Leone, for example, female combatants engaged in sexual violation of men. ${ }^{40}$ In the Congo, women were reported to have been involved in perpetrating 10 percent of the conflict-related sexual violence toward men. ${ }^{41}$

Much of the wartime sexual violence against men occurs in detention. In Bosnia and Herzegovina, sexual violence against men occurred primarily in detention camps. The forms of violence included rape, forced rape and incest, and multiple forms of genital violence, including circumcision, castration, electric shocks to the scrotum, amputation of the penis, and other forms of sexual mutilation. ${ }^{42}$ In Uganda, men were anally raped, "forced to penetrate holes in banana trees that run with acidic sap, to sit with their genitals over a fire, to drag rocks tied to their penis, to give oral sex to queues of soldiers, to be penetrated with screwdrivers and sticks." ${ }^{43}$ Prisoners have been forced to sexually brutalize one another, as exemplified by an incident in a Serbian detention camp in which a commander ordered two Bosnian prisoners to assault and cas-

36 Elements of Crimes, Rome Statute of the International Criminal Court, art. 8(2)(b)(xxii)6 (2011).

37 Rome Statute of the International Criminal Court, art. 7(1)(g), U.N. Doc. A/CONF.183/9, (1998).

38 Dustin A. Lewis, Unrecognized Victims: Sexual Violence Against Men in Conflict Settings Under International Law, 27 WIS. INT'L L.J. 1, 3 (2009). Lewis argues that the subject demands an appropriately broad definition, suggesting the following: "any violence, whether physical and/or mental, carried out through sexual means or by targeting sexuality." Id. Such a definition allows for the inclusion of:

"both physical and psychological attacks directed at a person's sexual characteristics," while also encompassing "all serious abuses of a sexual nature inflicted upon the physical or moral integrity of a person by means of coercion, threat of force or intimidation in a way that is degrading and humiliating for the victim's dignity."

$I d$. Oral and anal rape are included in this definition, including penetration with a penis, other body part, or an object. Id. at 11-12.

39 Onyango \& Hampanda, supra note 30, at 239-40; TAguba Report, supra note 11, at 16.

40 Physicians for Human Rights, War-Related Sexual Violence in Sierra Leone: A Population-Based Assessment 136 n.311 (2002).

41 Onyango \& Hampanda, supra note 30, at 239.

42 Gerecke, supra note 12, at 19.

43 Storr, supra note 32 (based upon interviews of Makerere University's Refugee Law Project and interviews with male victims of rape in Uganda). 
trate another Bosnian prisoner. ${ }^{44}$ The report to the International Tribunal for the Former Yugoslavia documented the chilling details of the attack:

After $\mathrm{G}$ and Witness $\mathrm{H}$ had been forced to pull Jasmin Hrnic's body about the hangar floor they were ordered to jump down into the inspection pit, then Fikret Harambasic, who was naked and bloody from beating, was made to jump into the pit with them and Witness $\mathrm{H}$ was ordered to lick his naked bottom and $\mathrm{G}$ to suck his penis and then to bite his testicles. Meanwhile a group of [Serbian] men in uniform stood around the inspection pit watching and shouting to bite harder. All three were then made to get out of the pit onto the hangar floor and Witness $\mathrm{H}$ was threatened with a knife that both his eyes would be cut out if he did not hold Fikret Harambasic's mouth closed to prevent him from screaming; $G$ was then made to lie between the naked Fikret Harambasic's legs and, while the latter struggled, hit and bite his genitals. G then bit off one of Fikret Harambasic's testicles and spat it out and was told he was free to leave. Witness $\mathrm{H}$ was ordered to drag Fikret Harambasic to a nearby table, where he then stood beside him and was then ordered to return to his room, which he did. Fikret Harambasic has not been seen or heard of since. ${ }^{45}$

As Dustin A. Lewis explains, each of the Bosnian detainees, is a victim as opposed to a perpetrator of sexual violence, having been forced by enemy commanders to rape and castrate another male detainee. ${ }^{46}$ Despite the detailed account of sexual violence against men in the report, the rape and castration of men in the Balkans conflict remained invisible, in sharp contrast to the publicity surrounding the rape of women.

In Syria, government forces have perpetrated sexual violence against men in detention. Reports of sexual abuse document government forces anally raping male detainees, with broken coke bottles, holding a man's legs apart and beating his genitals, and rape of boys. A member of the Political Security branch reported:

There is torture, but there is also rape for the boys. We would see them when the guards brought them back to the cell. It's indescribable. You can't talk about it. One boy came into the cell bleeding from behind. He couldn't walk. It was something they just did to the boys. We would cry for them. ${ }^{47}$

Other forms of sexual violence against men include the practice of forcing men to rape family members. During the occupation of Nanking during World War II, fathers were forced to rape their daughters and brothers to rape their sisters. ${ }^{48}$ In Bosnia, fathers and sons were forced to rape each other; fathers and brothers were forced to rape their female relatives. ${ }^{49}$ In Sierra Leone, "[t]he rebels have forced civilians to commit incest, one of the biggest taboos in any

44 Sandesh Sivakumaran, Male/Male Rape and the "Taint" of Homosexuality, 27 Hum. RTs. Q. 1274, 1295 n.107 (2005).

${ }^{45}$ Lewis, supra note 38, at 12 (citing Prosecutor v. Tadiæ, Case No. IT-94-1-T, Opinion and Judgment, II 206 (Int'l Crim. Trib. for the Former Yugoslavia May 7, 1997)).

46 See id. at 49; see also Sivakumaran, supra note 44, at 1298 (arguing that the "taint" of engaging in homosexuality, regardless of the presence of coercion is, in many countries, transmuted to victims forced into homosexual conduct with others, thereby subjecting them to anti-sodomy laws in their respective countries).

47 Syria: Sexual Assault in Detention, Hum. Rтs. WAтch (June 15, 2012), http://www.hrw .org/news/2012/06/15/syria-sexual-assault-detention.

48 R. Charli Carpenter, Recognizing Gender-Based Violence Against Civilian Men and Boys in Conflict Situations, 37 Security Dialogue 83, 95 (2006).

49 Id. 
society." 50 Forced incest and rape in front of family members violates fundamental cultural, social, and religious norms, compounding the sense of powerlessness and humiliation. As Charli Carpenter argues, "it is likely that such acts are deeply humiliating, violating private space, the sanctity of family relationships, and other cultural norms." 51 A similar practice involves forcing men to watch the rape of their wives and family members by enemy troops, which not only violates those who are raped, but inflicts serious emotional trauma upon the men who are powerless to protect their family members.

In another form of sexual violence, men and boys are frequently abducted for use as sexual slaves or child soldiers. In the Eastern territories of Congo, 20.3 percent of men reported being held as sexual slaves by opposition forces. ${ }^{52}$ In a study in Liberia, 16.5 percent of male combatants were forced to be sexual servants. ${ }^{53}$ Boys in Uganda and Afghanistan have been abducted for use as child soldiers and sex slaves. Human Rights Watch documented a number of cases involving the abduction, exploitation, and rape of boys by regional Afghan commanders and other members of the armed forces. ${ }^{54}$ The Afghan practice of "bacha baazi (boy play)," in which boys are kept and used for sexual entertainment, is common. ${ }^{55}$

Experts agree that the prevalence of sexual violence against men is vastly underreported. ${ }^{56}$ Post-conflict initiatives to address sexual violence have typically been focused on female victims, ${ }^{57}$ sending the message that women are the victims of sexual violence and discouraging men from seeking treatment or reporting their own rape and sexual violation. Even some healthcare workers fail to recognize men as victims. One therapist at the Centre for Psychotrauma in Croatia said she "had not believed that men could be raped until one night a man was brought in naked and bleeding from the anus.." 58

Rape or castration of male detainees or male prisoners of war remains deeply invisible. With the exception of Abu Ghraib, the sexual abuse of male detainees is well-hidden from the public. During the Balkans conflict, the rape of females was well-documented, yet the rape of men is "never a major story in the press, nor castration in a war camp on the evening television news." ${ }^{.59}$ In Syria, reports of rape of men by government forces have been publicized, but the majority of headlines in news reports refer to the rape of women and girls. A Human Rights Watch news report from June 15, 2012, for example, reads,

50 Id.

51 Id. at 96.

52 Onyango \& Hampanda, supra note 30, at 239.

53 Kirsten Johnson et al., Association of Combatant Status and Sexual Violence with Health and Mental Health Outcomes in Postconflict Liberia, 300 J. Am. Med. Ass'N 676, 681 (2008).

${ }^{54}$ See generally Hum. Rts. Watch, "Just Don't Call It A Militia": Impunity, Militias, and the "AfGhan Local Police" (2011), available at http://www.hrw.org/sites /default/files/reports/afghanistan0911webwcover_0.pdf.

${ }^{55}$ Sivakumaran, supra note 2, at 269.

56 See, e.g., Wynne Russell, Sexual Violence Against Men and Boys, 27 Forced MigraTION Rev. 22 (2007).

57 Buss, supra note 14, at 146.

58 Pauline Oosterhoff et al., Sexual Torture of Men in Croatia and Other Conflict Situations: An Open Secret, 12 Reprod. Health Matters 68, 74 (2004).

59 _arkov, supra note 22, at 71 . 
"Security Forces Also Attacked Women and Girls in Raids on Homes," despite reports that the Syrian government forces have also sexually tortured men and boys. ${ }^{60}$

In over 70 countries, homosexuality is a crime and male victims are even more reluctant to file a report with the police, who are often perceived to be anti-homosexual. ${ }^{61}$ In these places, a victim of rape by another man can be found guilty of engaging in homosexuality, a crime punished by the law. ${ }^{62}$ As Sandesh Sivakumaran explains, "[t]he difference between the term 'male/male rape' and the term 'homosexual rape' is not merely a semantic one ... [ [the term 'homosexual rape'] has been 'irrevocably tainted by years of use in a pejorative sense.' "63 The taboo against homosexuality in many places discourages male victims from reporting rape. ${ }^{64}$

Like female victims, men who are raped and sexually violated during war suffer serious health and sexual consequences. Survivors experience shame, guilt, anger, anxiety, suicidal thoughts, and disinterest in sex. ${ }^{65}$ Health workers report victims who have suffered from sexually transmitted infections, including HIV, genital infections, sexual impotence, swollen testicles, and abscesses and ruptures of the rectum. ${ }^{66}$ Male survivors of rape in the DRC have been found to be more likely than female survivors to suffer from depression and substance abuse and to commit suicide. ${ }^{67}$ Men who have been victims of castration or genital mutilation have even higher rates of suicide and depression. ${ }^{68}$

\section{B. Invisibility of Male Rape Under International Criminal Jurisprudence and Theory}

Despite its prevalence throughout ancient and contemporary history, maleon-male sexual violence is largely invisible in international criminal jurisprudence and theory. The international community has focused much attention on sexual violation of women and girls during armed conflict, but has largely ignored sexual violence against men and boys. ${ }^{69}$ As Lara Stemple argues, gender violence has largely become conflated with male violence against women in war. $^{70}$

60 Syria: Sexual Assault in Detention, supra note 47.

61 See, e.g., Gillian Mezey \& Michael King, The Effects of Sexual Assault on Men: A Survey of Twenty-two Victims, in Confronting Rape and Sexual Assault 83, 88 (Mary E. Odem \& Jody Clay-Warner eds., 1998). See also Emily Dugan, More Than 70 Countries Make Being Gay a Crime, InDEPENDENT (Aug. 1, 2010), http://www.independent.co.uk/news /world/politics/more-than-70-countries-make-being-gay-a-crime-2040850.html.

62 Sivakumaran, supra note 1 , at 256.

63 Sivakumaran, supra note 44 , at $1285-86$.

64 Oosterhoff et al., supra note 58 , at 68.

65 Id. at 71.

$66 I d$.

67 Onyango \& Hampanda, supra note 30, at 239.

68 Oosterhoff et al., supra note 58, at 71 .

69 See, e.g., Augusta DelZotto \& Adam Jones, Male-on-Male Sexual Violence in Wartime: Human Rights' Last Taboo? (Mar. 2002) (unpublished manuscript), available at http:// adamjones.freeservers.com/malerape.htm (arguing that analyses of sexual violence in war have been defined as "limited exclusively to female victims (as far as direct assaults are concerned, at least) and male perpetrators").

70 See Stemple, supra note 2, at 611. 
During the 1990s, feminists and human rights advocates successfully mobilized for the criminalization of rape under international law. ${ }^{71}$ The campaign by international feminist activists to recognize rape of women as a war crime was motivated in large part by the desire that "women's rights are human rights." 72 Hilary Charlesworth and others argued that international law failed to take seriously crimes of violence against women during armed conflict, rendering sexual violence by military troops invisible and outside the law of armed conflict. ${ }^{73}$

While rape has always been considered a violation of international law, ${ }^{74}$ the 1947 Geneva Convention Relative to the Protection of Civilian Person in Times of War and the 1977 Additional Protocols did not categorize rape as a "grave breach" or a crime of violence against women's bodily integrity. ${ }^{75}$ Instead, Article 27 of the Geneva Convention provided that "[w]omen shall be especially protected against any attack on their honour, in particular against rape, enforced prostitution, or any form of indecent assault." 76 By focusing on the harm to women's honor, international law essentially conceptualized wartime rape of women not as a harm to women's physical or sexual autonomy, but rather as a harm to her value to her husband, family, or community.

Following the widespread and highly publicized rape of tens of thousands of women during the Balkans conflict, feminists such as Rhonda Copelon, Catherine MacKinnon, and the Women's Caucus for Gender Justice sought to redefine the harm of wartime rape of women, reconceptualizing it from a crime of 'honour' to a means of war and crime against humanity. ${ }^{77}$ Largely as a result of this sustained advocacy, the International Criminal Tribunal for the former Yugoslavia (ICTY) recognized sexual violence as a distinct crime against humanity, a human rights violation constituting part of a widespread or systematic attack on a civilian population based upon ethnic, national, racial, political, or religious grounds. ${ }^{78}$ Similarly, in Prosecutor v. Jean-Paul Akayesu, the Rwandan Tribunal defined rape as a weapon of war that can constitute an act of genocide, a violent act by members of one group against another group as a means to destroy that group. ${ }^{79}$ In Akayesu, the Tribunal found an individual guilty of genocide on the basis, inter alia, of acts of rape and sexual violence. ${ }^{80}$ The ICTR found that "[t]he rape of Tutsi women was systematic and was per-

71 Id. at 625-27; Karen Engle, Feminism and Its (Dis)contents: Criminalizing Wartime Rape in Bosnia and Herzegovina, 99 AM. J. INT'L L. 778, 778-79 (2005).

72 Patricia Viseur Sellers, Gender Strategy is Not a Luxury for International Courts, 17 Ам.

U. J. Gender Soc. Pol'y \& L. 301, 305 (2009).

73 Engle, supra note 71 , at 782.

74 Id. at 778 .

75 See Alison, supra note 16 , at 82.

76 Geneva Convention Relative to the Protection of Civilian Persons in Times of War, art. 27, Aug. 12, 1949, available at http://www.icrc.org/applic/ihl/ihl.nsf/Article.xsp?action= openDocument\&documentId=FFCB180D4E99CB26C12563CD0051BBD9.

77 See Alison, supra note 16, at 82; Engle, supra note 71, at 784, 786-87.

78 S.C. Res. 827, U.N. Doc. S/RES/827 (May 25, 1993); Updated Statute of the International Criminal Tribunal for the Former Yugoslavia, art. 5(g), Sept. 2009.

79 Prosecutor v. Akayesu, Case No. ICTR-96-4-T, Judgement, II 731, 732 (Int'1 Crim. Trib. for Rwanda Trial Chamber I Sept. 2, 1998).

80 Id. at II 734; Russell-Brown, supra note 14, at 351 (discussing the intersectional analysis employed by the Rwandan Tribunal in recognizing rape as genocide). 
petrated against all Tutsi women and solely against them." ${ }^{\prime 1}$ Finding that "in most cases, the rapes of Tutsi women . . . were accompanied with the intent to kill those women," the ICTR found that rape was a means of genocide in the Rwandan conflict. ${ }^{82}$ Both tribunals were the first to prosecute wartime rape as a crime against humanity.

The ICTR in Akayesu broadly defined sexual violence as "any act of a sexual nature which is committed on a person under circumstances which are coercive." ${ }^{33}$ Significantly, the ICTR affirmed that "[s]exual violence is not limited to physical invasion of the human body and may include acts which do not involve penetration or even physical contact." 84 In many, though not all, of their other decisions, the ICTR and ICTY have relied upon the broad definition of sexual violence in Akayesu in a number of judgments of war crimes suspects charged with rape and sexual violence. ${ }^{85}$ The Rome Statute of the International Criminal Court, adopted in 2002, specifically criminalizes rape and many other forms of sexual violence that occur in armed conflict, defining sexual violence as a crime of war and crime against humanity. ${ }^{86}$ The definition of sexual violence is very broad - defined as "an act of a sexual nature against one or more persons or caused such person or persons to engage in an act of a sexual nature" committed by force, threat of force or coercion, or lack of consent. ${ }^{87}$ The Statute also specifically enumerates rape, sexual slavery, enforced prostitution, forced pregnancy, and enforced sterilization as crimes of war and crimes against humanity. ${ }^{88}$

In addition to securing the criminalization of sexual violence in war, feminist advocates raised the awareness of the international community about the specific harms to women during war. United Nations Security Council Resolution 1325 , adopted in 2000 , called upon all parties to armed conflict "to take special measures to protect women and girls from gender-based violence." 89 The Resolution expressed concern "that civilians, particularly women and chil-

81 Akayesu, ICTR-96-4-T at II 732.

82 Id. at $\mathbb{I}$ 731, 733-34.

83 Id. at II 688.

84 Id. For example, in Akayesu, the Tribunal considered the acts of undressing of a female student and forcing her to do gymnastics naked in a public courtyard to constitute sexual violence. $I d$.

85 See Prosecutor v. Musema, Case No. ICTR-96-13-A, Judgement and Sentence, II 220, 222-23 (Int'l Crim. Trib. for Rwanda Trial Chamber I Jan. 27, 2000); Prosecutor v. Delalić, Case No. IT-96-21-T, Judgement, II 478-79 (Int'l Crim. Trib. for the Former Yugoslavia Nov. 16, 1998). In other judgments, the Tribunals have used different versions of this definition. See Lewis, supra note 38, at 33-35.

86 Rome Statute of the International Criminal Court, art. 7(1)(g), art. 8(2)(e)(vi), U.N. Doc. A/CONF.183/9 (July 17, 1998).

87 Elements of Crimes, supra note 36, at art. 8(2)(b)(xxii)-6. The definition broadly defines force, threat of force, or coercion, adding to its definition "such as that caused by fear of violence, duress, detention, psychological oppression or abuse of power, against such person or persons or another person, or by taking advantage of a coercive environment or such person's or persons' incapacity to give genuine consent." Id.

88 Id. at art. 7(1)(g)-1-5, art. 8(2)(b)(xxii)-1-5.

89 S. C. Res. 1325, para. 10, U.N. Doc. S/RES/1325 (Oct. 31, 2000). For a full discussion of the disproportionate focus in international instruments, including the Convention for the Elimination of Violence Against Women, see Stemple, supra note 2, at 619-22. 
dren, account for the vast majority of those adversely affected by armed conflict . . . and increasingly are targeted by combatants and armed elements." 90

At the same time, wartime rape and sexual violence against men and boys has been largely absent or marginalized in international criminal jurisprudence. $^{91}$ While the international tribunals for the former Yugoslavia and Rwanda documented instances of rape and sexual violence against men, sexual violence against men largely remained "an open secret," observed by international aid workers yet invisible to the rest of the world. ${ }^{92}$ The Report of the U.N. Commission of Experts charged with investigating sexual violence during the Balkans conflict, for example, evidences numerous incidences of the rape of male victims. ${ }^{93}$ The Report documented castrations of men "performed through crude means such as, forcing one internee to bite off another's testicles." ${ }^{94}$ Another report by the Special Rapporteur of the Commission on Human Rights included testimony of a witness who had observed "the corpses of 15 young men whose genitals had been mutilated." ${ }^{95}$ Health workers in refugee camps and post-conflict zones in the former Yugoslavia and other conflict locations similarly reported incidents of male victims of sexual violence by men. ${ }^{96}$

International criminal courts, however, have not focused serious attention on male victims. ${ }^{97}$ On the positive side, the ICTY proceedings have resulted in the documentation of incidents of sexual abuse of men. In Prosecutor $v$. Delalić, for example, the ICTY convicted three defendants for the acts of subordinates, including placing burning fuse cords around the genitals of male detainees and forcing two detainees to perform oral sex on each other. ${ }^{98}$ In Prosecutor v. Du [Ko Tadi], the defendant was convicted of various abuses against detainees, including ordering two male detainees to perform oral sex on a third male detainee and bite off his testicles. ${ }^{99}$ ICTY judgments also found that male detainees were subject to sexual assaults, recounting an incident in which a police truncheon was rammed into the anus of a male detainee, and incidents involving forcing male prisoners to perform oral sex on each other,

90 S. C. Res. 1325, U.N. Doc. S/RES/1325 (Oct. 31, 2000).

91 See Valerie Oosterveld, Atrocity Crimes Litigation Year-in-Review (2010): A Gender Perspective, 9 Nw. J. Int'L Hum. Rts. 325, 326, 331 (2011).

92 Oosterhoff et al., supra note 58, at 71-74.

93 U.N. S.C. Rep. of the Commission of Experts Established Pursuant to Security Council Resolution 780 (1992), II 232, 235-36, 242-53, U.N. Doc. S/1994/674 (May 27, 1994).

94 Id. at II 250(d); Sivakumaran, supra note 1, at 265.

95 Report on the Situation of Human Rights in the Territory of the Former Yugoslavia submitted by Mr. Tadeusz Mazowiecki, Special Rapporteur of the Commission on Human Rights, pursuant to Commission resolution 1992/S-1/1 of 14 August 1992, Comm. on Human Rights, 49th Sess., II 63, E/CN/4/1993/50 (Feb. 10, 1993).

96 Oosterhoff et al., supra note 58, at 71.

97 Grey \& Shepherd, supra note 1, at 116 (gender-based violence against men has been marginalized in international criminal jurisprudence); Sivakumaran, supra note 2, at 261.

98 Prosecutor v. Delalić, Case No. IT-96-21-T, Judgement, II 24, 26 (Int'l Crim. Trib. for the Former Yugoslavia Nov. 16, 1998).

99 Prosecutor v. Du [Ko Tadi], Case No. IT-94-1-T, Opinion and Judgment, II 206 (Int'1 Crim. Trib. for the Former Yugoslavia May 7, 1997). 
often in front of other prisoners or commanders. ${ }^{100}$ In Prosecutor v. Čečić, a Serbian commander was found to have forced two Muslim brothers to perform oral sex on each other, sometimes in front of other prisoners. ${ }^{101}$

None of these ICTY decisions, however, specifically found these acts to be crimes of rape or sexual violence. In fact, in Tadić, the ICTY convicted four commanders from the Bosnian Omarska detention camp for having inflicted a "hellish orgy of persecution." 102 The majority of the detainees were male and the prosecution alleged that both female and male prisoners were beaten, tortured, raped, and sexually assaulted. ${ }^{103}$ In presenting the charges though, the ICTY did not categorize the rape or castration of male detainees as "rape"which by itself constituted a crime against humanity under ICTY statutes-but rather as examples of "great suffering or serious injury to body or health," "cruel treatment," and "inhumane acts." ${ }^{104}$ In contrast, the ICTY specifically charged the rape of a female detainee in the camp as "rape" and "forcible sexual intercourse." 105

In cases in which acts of sexual violence and rape of men have been recognized by the International Tribunals, scholars have noted that the prosecutors and tribunals have tended to categorize sexualized violence against men not as gender-based violence, but as "torture" or "abuse," particularly where the violence is directed at male detainees and prisoners of war. ${ }^{106}$ This results in a failure to provide humanitarian assistance and medical treatment for male victims of rape and other forms of sexual abuse. ${ }^{107}$ Even more importantly, the failure to characterize sexual abuse of men during war as sexual or genderbased violence obscures the sexualized nature of the conduct. This erasure has several negative effects. First, it ignores the emotional and physical damage suffered by men from the loss of their sexual autonomy and dignity. Second, it renders invisible the gendered meanings of sexual violence against men. Third, it serves to normalize the deliberate use of rape and sexual violence by armed forces.

In a positive development, the Special Court for Sierra Leone recently successfully prosecuted sexual violence against men committed by the Revolutionary United Front (RUF). ${ }^{108}$ In Prosecutor v. Sesay, the Trial Chamber found in 2010 that the RUF troops committed gender-based acts against men

100 Prosecutor v. Simić, Case No. IT-95-9-T, Judgement, II 728 (Int'l Crim. Trib. for the Former Yugoslavia Oct. 17, 2003).

101 Prosecutor v. Čečić, Case No. IT-95-10/1-S, Sentencing and Judgement, II 13 (Int'l Crim. Trib. for the Former Yugoslavia March 11, 2004).

102 DelZotto \& Jones, supra note 69.

103 Id.

104 Id.

105 Id.

106 See Sivakumaran, supra note 1, at 256. See also Rosalind P. Petchesky, Rights of the Body and Perversions of War: Sexual Rights and Wrongs Ten Years Past Beijing, 184 INT'L Soc. ScI. J. 301, 312 (2005).

107 See, e.g., Carpenter, supra note 48 ("while the humanitarian assistance community has taken strides in addressing the physical and psycho-social needs of female rape survivors, it has been noted that services for male survivors of such violence in conflict situations are nearly non-existent.").

108 Oosterveld, supra note 1, at 50, 70 (noting the failure of the ICTY and ICTR to prosecute rape and sexual violence against male victims). 
and boys "as part of a reign of terror," including slitting the sexual organs of male captives, forcing male abductees to rape female abductees, forcing nudity of male captives, along with the forcible recruiting of boys as child soldiers. ${ }^{109}$ The Sesay judgment not only recognized the male victims of different forms of sexual violence committed by the RUF, but linked the violence to a campaign of terror in which sexual violence against both men and women was used as a weapon of war.

Unfortunately, other courts continue to refuse to conceptualize sexual violence against men as gender-based violence. In 2010, the Pre-Trial Chamber of the ICC authorized the "investigation into crimes against humanity committed in Kenya during post-election violence in 2007." 110 The Prosecutor applied to the Chamber for Summons to Appear for high-ranking Kenyans accused of various crimes against humanity including the forced circumcision and genital mutilation of Luo men with objects such as broken glass that resulted in some instances of genital amputation. ${ }^{111}$ The Prosecutor sought to reclassify the acts of forced circumcision as a form of "sexual violence" versus other inhumane acts causing serious injury, which the Prosecutor originally used to describe the acts. ${ }^{12}$ The Chamber rejected the reclassification request, stating without explanation that forced circumcision is not an act of a sexual nature. ${ }^{113}$ Valerie Oosterveld, a leading feminist scholar and advocate for female victims of wartime violence, concludes that "international criminal law is still rather undeveloped in its understanding of sexual violence, and, more broadly, gender-based violence, directed against men and boys during times of war or other widespread or systematic violations." 114

The United Nations, nevertheless, has begun to recognize the prevalence of sexual violence against men during war. The UN Secretary-General reported in 2009 that " $[w]$ hile women and girls are particular targets and are the majority of the victims of sexual violence, the case-law of the International Criminal Tribunal for the Former Yugoslavia (ICTY) and the Special Court for Sierra Leone (SCSL) also bears testimony to the use of sexual violence against men." 115 UN Security Resolution 1888, adopted that same year, addresses sexual violence of civilians during wartime and uses gender-neutral language that includes both male and female victims of wartime violence. ${ }^{116}$ This shift has at least begun to address concerns that international law originally addressed sexual violence in war in Resolution 1325 as an issue that solely affected women

109 Oosterveld, supra note 91, at 334; see also Prosecutor v. Sesay, Case No. SCSL-04-15T, Judgment, II 1067, 1207-08, 1616 (Special Ct. for Sierra Leone Mar. 2, 2009).

110 Oosterveld, supra note 91, at 331; Situation in the Republic of Kenya, Case No. ICC-01/ 09, Decision Pursuant to Article 15 of the Rome Statute (Int'l Crim. Ct. Mar. 31, 2010).

111 Prosecutor v. Ruto, Kosgey \& Sang, Case No. ICC-01/09-01/11, Decision on the Prosecutor's Application for a Summons to Appear, II 57, 59 (Int'l Crim. Ct. Mar. 8. 2011).

112 Prosecutor v. Muthaura, Kenyatta \& Ali, Case No. ICC-01/09-02/11, Decision on the Prosecutor's Application for Summonses to Appear, II 27 (Int'l Crim. Ct. Mar. 8. 2011).

113 Id.

114 Oosterveld, supra note 91, at 334.

115 U.N. Secretary-General, Report of the Secretary-General Pursuant to Security Council Resolution 1820 (2008), U.N. Doc. S/2009/362 II 6 (Aug. 20, 2009).

116 See S.C. Res. 1888, U.N. Doc. S/RES/1888 II 3 (Sept. 30, 2009). 
and girls. More recently, the Security Council has recognized the need to provide services to male victims of wartime sexual violence. ${ }^{117}$

\section{Inadequate Theorization of Sexual Violence Against Men in War by Feminists}

While legal scholars and some feminists have begun to recognize the invisibility of male victims of wartime sexual violence, rape of men during wartime has not been adequately theorized. ${ }^{118}$ As discussed above, international feminist scholars were extremely successful in persuading international law to recognize wartime rape of women as a crime against humanity and instrument of genocide, shifting the social meaning of rape from an individual attack on a woman's honor to a criminal act of war and crime against humanity. The feminist campaign to recognize rape and sexual violence as a crime of war, however, focused exclusively on female victims.

Recently, scholars have begun to focus on male victims of sexual violence. ${ }^{119}$ Much of the scholarship, however, critiques feminist accounts of sexual violence against women, but-with a few notable exceptions, including Sivakumaran and Alison-does not adequately explain the nature or impact of violence against male victims as a gendered practice. Scholars such as Lara Stemple, for example, criticize the feminist campaign to criminalize rape in a war as grounded in notions of male dominance and female subordination. ${ }^{120}$ These critics argue that the campaign to recognize sexual violence against women in wartime rested upon gendered narratives that essentialize men as perpetrators and women as victims. ${ }^{121}$ According to these scholars, this approach disallows consideration of male rape or a gender analysis that takes into account the complexities of male on male violence. ${ }^{122}$ Grey and Shepherd, for example, argue that feminist claims that wartime sexual violence disproportionately affects women "suggest that sexual violence against men is somehow separate from broader gendered power dynamics while sexual violence against women is symptomatic of these dynamics." 123

Halley refers to this approach as "feminist universalism" and goes so far as to assert that " $[\mathrm{t}$ ]his framing [of female universalism] reproduces in reverse

117 UN Forum Highlights Plight of Male Victims of Sexual Violence in Conflict, UN News CENTRE, (July 30, 2013), http://www.un.org/apps/news/story.asp?NewsID=45532\#. UyZYcV5kLsI.

118 See Sivakumaran, supra note 1, at 253, 255; see also Sivakumaran, supra note 2, at 261.

119 See, e.g., Halley, supra note 13, at 86-87. See generally Lewis, supra note 38, at 2; Stemple, supra note 2, at 605-44.

120 Stemple, supra note 2, at 634 ("Male rape will only be curtailed when the perception of men broadens beyond one that sees men as a monolithic perpetrator class," therefore making it impossible to understand sexual violence against men). See also Grey \& Shepherd, supra note 1 , at 120 (criticizing feminist accounts of sexual violence in war as "sex-specific" articulations that "function[] to normalize 'sexual and reproductive' violences against women, while simultaneously rendering similar violences against men abnormal or "exceptional" "). 121 See, e.g., Stemple, supra note 2, at 634. See also Grey \& Shepherd, supra note 1, at 120.

122 Stemple, supra note 2, at 634 ("Assumptions that real men are sexual aggressors and never victims promote harmful perceptions about the 'one' way to be a man. They can justify violent behaviors as an archetypal manifestation of maleness . ...").

123 Grey \& Shepherd, supra note 1 , at 120. 
the blind-spotted moral vision that it contests. . . [I]t involves a-to me absolutely chilling-indifference to the suffering and death of men." ${ }^{124}$ In Real Rape Too, Bennett Capers similarly criticizes feminist dominance theorists for excluding the rape of men from consideration. ${ }^{125}$ While his article discusses the law of rape in the United States, he includes rape of men in war within his larger analysis. He writes that "[I]n arguing for reform, many feminist scholars have inadvertently legitimized and contributed to the very gender distinctions of which they have been so critical. In response to one form of subordination, they have entrenched another." 126

While it is true that early feminist activists focused solely on women as victims, it is also true that male victims of sexual violence arguably have been even more hidden and stigmatized than female victims. Rape of men has been normalized as torture or an unlawful deviation from the rules of war that is arguably to be expected as part of the horrors of war. Sexual violence that occurs in detention against male detainees or enemy combatants has occurred within the walls of detention camps, largely hidden from public view. The sexual abuse of Iraqi detainees in Abu Ghraib, for example, would have remained hidden except for the actions of US troops in photographing and emailing some of the incidents, which actually violated military policy. ${ }^{127}$ Unlike female or male civilians, who are considered "innocent" victims, victims of rape who are combatants or detainees may be perceived as less worthy of protection.

Rather than merely criticize early feminist activists for focusing primarily on sexual crimes against women, feminist scholars need to begin to theorize how sexual violence against men functions as a gendered weapon of war. To persuade international courts to recognize crimes involving sexual violence against men as sexual crimes requires that we fully explore and theorize the gendered nature and consequences of this violence. The ICC Chamber that refused to classify forced circumcision of Kenyan men as sexual violence, for example, would benefit from understanding how this form of violence is particularly gendered in its meaning and impact.

It is essential to recognize the rape and sexual violence against male victims as violations of human rights equally deserving of condemnation as crimes against humanity and means of genocide, just as international law has done for female victims. Unlike Halley and Capers, I argue that the earlier work of Copelon and other feminists in theorizing gender violence within a dominance framework can provide an important foundation for examining sexual violence against men in war. Masculinities theory, as I argue below, can provide critical

124 Halley, supra note 13 , at 123.

125 Capers, supra note 13, 1265. Capers argues:

$[R]$ ape law has been gendered for too long. Originally, it was gendered in a way that tilted the scales to benefit men-men as fathers, men as husbands, and men as rapists. Feminists were right to point out the sexism inherent in traditional rape laws in this country, though many, including Catharine MacKinnon, were wrong to view rape as solely a mechanism of male domination of women.

Id.

126 Id.

127 Nick Juliano, New Yorker: Abu Ghraib Abuses Were 'De Facto US Policy', Raw STORY, (Mar. 17 2008), http://rawstory.com/news/2008/New_Yorker_Abu_Ghraib_abuses _were_0317.html. 
insights that allow us to see how sexual violence against both men and women functions as a means to empower particular groups of men in specific spaces during conflict.

\section{Making Men Visible as Victims of Sexual Violence During War: A Masculinities Approach}

The invisibility of male sexual violence against men is not simply a product of feminist dominance theories failing to recognize men as victims. The silence around male rape in war reflects the power of social constructions of masculinity that define men as powerful, sexually dominant, and heterosexual. "Real men," according to this gendered script, are not raped. ${ }^{128}$ Sexual violence against men in war is not merely about abusing an individual person, nor the aberrant action of a single deviant actor. The use of sexual violence against men in war, as Sivakumaran argues, is about masculine domination and power just as it is for women. ${ }^{129}$

Rather than erase gender or male dominance from the analysis of wartime sexual violence against men, I argue, the better approach is to broaden the notion of gender in international law to include the social construction of masculinity that privileges some men, while disadvantaging women and most men. Focusing on the use of masculinized social practices, including the construction of manhood and masculinity within armed conflict, provides a basis for understanding and addressing violence against both men and women in war.

Drawing upon feminist dominance and social constructivist theories, this approach broadens the class of victims to include men as well as women, integrating social constructivist theories that examine the intersection of gender, ethnicity, race, nationalism and other structures of subordination. Instead of analyzing rape of men as separate and distinct from rape of women, this approach posits that acts of sexual violence toward men and women are related and mutually reinforcing, operating within particular institutions and social systems of gender that privilege and empower masculinity as male and heterosexual.

\section{A. The Masculinities of War}

Masculinities theory helps explain the use of sexual violence against both men and women in war as a masculinized practice that is deployed by particular groups. Rather than constituting a category of identity, masculinity is a social practice, created by and through men and the opposition to femininity. ${ }^{130}$ As R. W. Connell argues, masculinity is "simultaneously a place in gender relations, the practices through which men and women engage that place in gender, and the effects of these practices in bodily experience, personality and

128 See I. Bennett Capers, Real Women, Real Rape, 60 UCLA L. Rev. 826, 829 (2013) (defining "rape scripts" as "those assumptions we hold about what rapists look like, what constitutes rape, and most important here, what rape victims look like").

129 Sivakumaran, supra note 1 , at 267.

130 Connell, supra note 24 , at 68. 
culture." ${ }^{131}$ Masculinities theorists posit that masculinity is not fixed, but rather relational and contingent, varying across time and place. ${ }^{132}$

In practice, masculinity is constructed "in front of and for other men and against femininity." 133 As French sociologist Pierre Bourdieu explains, "manliness must be validated by other men, in its reality as actual or potential violence, and certified by recognition of membership of the group of 'real men." "134 A critical insight of masculinities theory is the tenet that masculinity is never quite attained by any individual man. ${ }^{135}$ Within groups of men, rituals and social practices are used to test the masculinity of individual men while simultaneously reinforcing the solidarity of the group. ${ }^{136}$

Sexualized violence during wartime functions as such a masculinized practice, both within particular military organizations as well as among and between particular groups of men and larger collectives. Within militaries and armed groups, warriors historically have been constructed as male and masculine. ${ }^{137}$ As Joshua Goldstein argues in War and Gender, war and gender are reciprocal: warriors are constructed as masculine, and masculinity is constructed through war. ${ }^{138}$ Despite the social construction of warriors as masculine, war does not come naturally to men or women. "War is hell," as General MacArthur said. ${ }^{139}$ In World War II, approximately one-quarter of evacuated troops were not physically injured, but were overwhelmed by battle, "shaking, or stunned, unable to hear or talk." ${ }^{140}$ Research indicates that the military specifically trains military recruits (male and female) to be "masculine" and violent in order to create soldiers who are willing to kill to protect the nation or other collective group. ${ }^{141}$ The violent masculinity promoted by militaries is often contrary to the human values in society, requiring institutional practices to continuously enforce such norms. ${ }^{142}$

To induce soldiers to fight, the military compels recruits (male or female) to prove their masculinity. Through a range of social and institutional practices,

131 Id. at 71 .

132 R. W. Connell \& James W. Messerschmidt, Hegemonic Masculinity: Rethinking the Concept, 19 Gender \& Soc. 829, 836 (2005).

133 Pierre Bourdieu, Masculine Domination 53 (Richard Nice trans., 2001).

134 Id. at 52.

135 See Kimmel, supra note 19, at 229; Russell K. Robinson, Masculinity as Prison: Sexual Identity, Race, and Incarceration, 99 CALIF. L. REv. 1309, 1332 (2011).

136 Bourdieu, supra note 133, at 52.

137 David H. J. Morgan, Theater of War: Combat, the Military, and Masculinities, in THEORizing MAsculinities 165, 165 (Harry Brod \& Michael Kaufman eds., 1994) ("Despite farreaching political, social, and technological changes, the warrior still seems to be a key symbol of masculinity.").

138 Goldstein, supra note 3, at 265-66.

139 Id. at 253 .

$140 \mathrm{Id}$. at 258.

141 See, e.g., Fionnuala Ní Aoláin et al., Masculinities and Child Soldiers in Post-Conflict Societies, in Masculinities and the Law: A Multidimensional Approach 231, 235 (Frank Rudy Cooper \& Ann C. McGinley eds., 2012); Connell, supra note 24, at 259; Goldstein, supra note 3, at 252.

142 Barbara Ehrenreich, Blood Rites: Origins and History of the Passions of War 10-12 (1997). 
militaries typically construct masculinity as the opposite of femininity. ${ }^{143}$ In the US military, for example, a "variety of rituals and practices compel males to prove their social identity as men through both the symbolic and actual enactment of a hypermasculinity that denigrates women." 144 Drill sergeants humiliate recruits by calling them "pussies," "sissies," or "fags."145 Cadence calls "often denigrate women or celebrate male sexual domination of women." ${ }^{146}$ In the late 1980s, the Naval Academy glee club's favorite tune was “ 'The S\&M Man,' sung to the tune of 'The Candy Man:' " "Who can take a chain saw/Cut the bitch in two/Fuck the bottom half/and give the upper half to you." 147

Because masculinity is defined as heterosexual, other military rituals and practices employ male-on-male sexual violence to construct masculinity as dominant. ${ }^{148}$ In 1994, "ABC broadcast videotapes documenting sado-sexual hazing practices in the elite Marine Corps silent drill team during 'Hell Night," "which was the culmination of a grueling training program. ${ }^{149}$ The videos showed a team leader painting military shoe polish on the genitals of a new drill team member. ${ }^{150}$ A 2012 study by the Veterans Administration disclosed that 55,491 male veterans treated by the Veterans Administration-one out of every 100-reported a history of military sexual trauma by peers or superiors during their military careers. ${ }^{151}$ Reports of sexual abuse and violence have occured in other nations, as well. ${ }^{152}$ In Australia, for example, a 2012

143 See, e.g., Mady Wechsler Segal, Military Culture and Military Families, in BEYOND Zero Tolerance: Discrimination in Military Culture 251, 256 (Mary Fainsod Katzenstein \& Judith Reppy eds., 1999).

144 See, e.g., Valorie K. Vojdik, Beyond Stereotyping in Equal Protection Doctrine: Reframing the Exclusion of Women from Combat, 57 AlA. L. Rev. 303, 342 (2005) (analyzing social practices that construct militaries as masculine).

145 Id.

146 Id.

147 Id.

148 See, e.g., Valorie K. Vojdik, The Invisibility of Gender in War, 9 DuKE J. GENDER L. \& POL'y 261, 267 (2002) (discussing the masculinized construction of male recruits in the US military).

149 Id.

150 Id.

151 Dep't of Veterans Affairs, Military Sexual Trauma (2013), available at http:// www.mentalhealth.va.gov/docs/mst_general_factsheet.pdf. See also DeP'T of VeterAns Affairs, Military Sexual Trauma Fact Sheet (Nov. 2013), available at http://www .mentalhealth.va.gov/docs/MST_Fact_Sheet_11-2013.pdf. See generally Baltimore Sun, Men Sexually Assaulted in the Military Speak Out, Military (Dec. 20, 2013), http://www .military.com/daily-news/2013/12/20/men-sexually-assaulted-in-the-military-speak-out.html (discussing different incidents of male veterans who have been sexually assaulted); Moni Basu, Veteran Confronts Rape, Suicide: "I Am Angry That Others Are Going Through This”, CNN (Sept. 21, 2013, 2:22 PM), http://www.cnn.com/2013/09/21/us/military-suicide -rape/ (discussing the prevalence of suicide for male sexual assault victims).

152 See, e.g., Richard Evans, Hazing in the ADF: a Culture of Denial?, 10 Austr. Army J. 113 (2013) (discussing the prevalence of sexual violence through hazing in the Australian Defense Force); Carlos Linhares de Albuquerque \& Eduardo Paes-Machado, The Hazing Machine: The Shaping of Brazilian Military Police Recruits, 14 Policing \& Soc'y. 175, 184 (2004) (documenting use of anti-women and homophobic language, forced cross-dressing and other acts of humiliation that reflect masculine norms in Brazilian training of military police). 
report investigated claims of sexual abuse by almost 850 members of the Australian Defence Forces, including sodomy, rape, and sexual assault. ${ }^{153}$ The report found nearly all of the claims credible. ${ }^{154}$

Because gender is separate and distinct from biological sex, female soldiers as well as male soldiers are socialized to exhibit this militarized aggressiveness, thus explaining the participation of female soldiers in sexual violence against male detainees. The masculinization of soldiers, both male and female, explains the involvement of female troops in the rape and sexual violation of men in Abu Ghraib, in which female soldiers participated in the sexual abuse and humiliation of Muslim male Iraqi detainees. Women also have perpetrated sexual violence in war, against both men and women. ${ }^{155}$ Women were in command positions in the Bosnian conflict, Rwanda, and Sierra Leone. ${ }^{156}$ In Sierra Leone, women were participants in one out of four gang rapes, along with men; women were rumored to be especially vicious fighters and had a reputation for encouraging excessive violence. ${ }^{157}$ A 2010 population survey in the Democratic Republic of Congo found that 41 percent of female sexual violence victims and 10 percent of male victims reported that they were victimized by female perpetrators. ${ }^{158}$

Sexual violence, and particularly gang rape of women, is used as a means to recruit and socialize male combatants in conflicts involving forced recruits. ${ }^{159}$ Groups that recruit new members through forcible means, such as abduction, "face a central dilemma; namely, such groups must create a coherent fighting force out of a collection of strangers, many of whom had to be abused in order to compel them to join." ${ }^{160}$ Male rape of women during war is a wellrecognized practice of armed groups and militaries; it functions to construct and enforce group cohesion within armed groups. ${ }^{161}$ Gang rape also functions to solidify a group and to increase morale. Human Rights Watch, for example, has documented the use of gang rape to bond male recruits during the civil war in Sierra Leone. ${ }^{162}$ A study by Anna Maedl of male gang rape of women in the

153 Evans, supra note 152, at 114.

154 Id.

155 Stemple, supra note 2, at 608 n.19.

156 Megan Gerecke, Explaining Sexual Violence in Conflict Situations, in Gender, War, AND Militarism 138, 152 n.7 (Laura Sjoberg \& Sandra Via eds., 2010).

157 Dara Kay Cohen, Female Combatants and the Perpetration of Violence: Wartime Rape in the Sierra Leone Civil War, 65 World Politics 383, 383-85, 399 (2013).

$158 I d$. at 385.

$159 I d$. at 392.

160 Dara Kay Cohen, Causes of Sexual Violence During Civil War: Cross-National Evidence (1980-2009), at 3 (Mar. 28, 2011) (unpublished manuscript).

161 See Anna Maedl, Rape as Weapon of War in the Eastern DRC? The Victims' Perspective, 33 Hum. RTs. Q. 128, 141 (2011) (“Additionally, some authors have suggested that gang rapes serve internal group purposes. They could establish hierarchy within armed groups, i.e. the highest man in the hierarchy rapes a woman first and so on, and they are thought to increase male group bonding through the common experience of rape and to overcome moral barriers through group pressure. The data suggests that armed groups organize and act together to rape civilian women."). See also Elisabeth Jean Wood, Variation in Sexual Violence During War, 34 Pol. \& Soc'y 307, 327 (2006).

162 New Testimony of Rape Committed by Sierra Leone Rebels, Hum. RTs. W Aтch (June 5, 2000), http://www.hrw.org/print/news/2000/06/05/new-testimony-rape-committed-sierra -leone-rebels. 
Congo confirmed evidence that heavily armed, hierarchically structured groups perpetrated gang rapes of women as part of their military activity. ${ }^{163}$ The study documents that in the Congo, gang rape of women by armed groups was an inherent part of the groups' conduct, conducted by members under order from their superiors. ${ }^{164}$

As Goldstein explains, rape is used to "control a chaotic and fearsome external world while proving manhood and toughness to one's buddies within the military 'family.' "165 The acceptance of sexual violence within a military, especially in small units, creates conformity and status within the group that repeatedly encourages impunity. ${ }^{166}$ Gang rape by groups of men is a collective act of humiliation and dominance that "seals [their] allegiance in atrocity." 167 It is the specific taboo against rape and sexual violence that is used to create group cohesion. ${ }^{168}$ Consider the description of the use of gang rape by an elite Serbian military group, the White Eagles, during the Balkans conflict:

White Eagles have made rape a gesture of group solidarity. A man who refuses to join the others in rape is regarded as a traitor to the unit, and to his Serbian blood. Sometimes, that impulse to bond with the male group becomes a kind of perverse inflaming energy inciting to rape. Lust is only a subsidiary drive. . . The rape is proof of commitment to the unit's fierceness. A young man willing to do hideous things has subordinated his individual conscience in order to fuse with the uncompromising purpose of the group. A man seals his allegiance in atrocity. ${ }^{169}$

While cultures of military forces undoubtedly differ across time and place, the tendency of military institutions to embrace violent forms of masculinity is apparent. Through a myriad of social and institutional practices, military institutions tend to construct warriors as masculine and dominant, enforcing a violent form of masculinity that, as Goldstein argues, is considered necessary to inculcate the ability to kill among ordinary citizens. It is not surprising, then, that military groups often use sexual violence against men and women as a weapon of war to dominate the enemy in specifically sexual and gendered ways, as discussed below. ${ }^{170}$

\section{B. Theorizing Sexual Violence Against Men as a Gendered Weapon of War}

Using the lens of masculinity theory, sexual violence can be seen as a gendered tool of war that constructs and reinforces hegemonic masculinity as a

163 Maedl, supra note 161, at 142.

164 Id.

165 Goldstein, supra note 3, at 365.

166 Id.

167 Lance Morrow, Unspeakable: Rape and War, Time, Feb. 22, 1993, at 48. See generally Madeline Morris, By Force of Arms: Rape, War, and Military Culture, 45 Duke L.J. 651, 652 (1996) (analyzing rape of women by US military troops).

168 Gerecke, supra note 12, at 53 ("The specific taboo attached to sexual violence (rather than violence by combatants in general) was a useful way to create group cohesion, creating a 'brotherhood in guilt.' ").

169 Id. at 52 (citation omitted).

170 See Goldstein, supra note 3, at 283. See also Wood, supra note 161, at 326 ("One result of such practices is that soldiers then represent domination of the enemy in a gendered way, leading to the use of specifically sexual violence against enemy women and, occasionally, against enemy men who are dominated through male rape and castration.”). 
means to empower specific groups during conflict. Wartime sexual violence as a masculinized social practice, moreover, intersects with gender, ethnicity, and national identities, marking the perpetrators as dominant while subordinating the enemy group. Rather than merely perpetuate male domination over women, wartime sexual violence against men functions on multiple levels to engender dominance of particular groups during war.

First, the actual enactment of rape and sexual violence against male combatants and detainees, like violence against women, is a means of feminizing the enemy while constructing the military perpetrators as masculine. ${ }^{171}$ Throughout history, as Goldstein observes, militaries have constructively feminized the enemy as a means of constructing themselves as masculine and dominant to motivate troops to fight. The feminization of the enemy occurs at both the symbolic and material levels. Goldstein offers numerous examples of the "symbolic castration" of enemy countries, such as statements made by President Lyndon Johnson describing US casualties on Vietnamese soldiers during the Tet Offensive: "I didn't just screw Ho Chi Minh. I cut his pecker off!"172 Goldstein further offers examples of military troops describing the enemy as female and military victories in terms of sexualized violence. As an example, he refers to a US pilot flying sorties during the first Iraq war who exclaimed, "[I] cold smoked the bitch!" ${ }^{773}$ In both cases, military troops symbolically construct themselves as the powerful masculine warrior and the enemy as emasculated and powerless or female and vanquished.

The rape of men during war, like the rape of women, is not about sexual desire but rather masculine domination. ${ }^{174}$ Feminist theorists such as Catharine MacKinnon argue that rape accomplishes the masculine domination of women. As Sivakumaran and others observe, sexual violence against men by combatants serves a similarly gendered function; it symbolically masculinizes the perpetrator as dominant and aggressive, while symbolically constructing the enemy men, who are violated, as stereotypically feminine, weak and powerless. When men are raped, they symbolically lose their gender identity as men-who are socially constructed to dominate-and are feminized and socially constructed as the female victim. ${ }^{175}$ The rape of men thus turns the male into a powerless victim, a symbolic woman who is sexually violated by the perpetrator through rape. Further, the male victim of rape also loses one of the basic attributes of masculinity - his ability to protect his family and community. ${ }^{176}$ If

171 See, e.g., Onyango \& Hampanda, supra note 30, at 241 ("Socially constructed notions of gender and sexuality can also provide motivation for perpetrators to commit sexual violence against men in armed conflict settings. For example, leaders often tell soldiers that to be a real man is to assert a militaristic, masculine dominance and emasculate other men. Sexual violence against the perceived enemy, either male or female, is one way of expressing this notion of masculinity.").

172 Goldstein, supra note 3, at 358.

$173 I d$. at 356.

174 See Sivakumaran, supra note 2, at 276.

175 Id. at 265-66.

176 See, e.g., Onyango \& Hampanda, supra note 30, at 241 (“' $[\mathrm{M}]$ en who become helpless and are overpowered by other males may be judged to have failed in their masculine duty. Therefore, compared with female survivors, males become more stigmatized, ashamed with their situation, and less likely to report the incident or seek help."). 
a man cannot protect himself from rape by enemy forces, then he appears powerless to protect the women and children in his family or community. Male victims are shamed and stigmatized as weak and effeminate, unable to protect themselves from male aggression. ${ }^{177}$

This stigma encourages men to remain silent and not report sexual violence rather than face the consequences of stigmatization, fear of rejection, or disbelief by others. ${ }^{178}$ One man who was abducted during the conflict in the Congo and used as a sexual slave for opposing forces, raped repeatedly, explained that after he reported the abuse, members of his village derided him for losing his masculinity, calling him "a bush wife" and ostracizing him from his community. ${ }^{179}$ The shame and stigma, some argue, appear to be even greater for men than women. ${ }^{180}$

Male survivors may suffer from even more marginalization than females as a result of these masculine social norms. ${ }^{181}$ As mentioned earlier, the stigma and shame for male victims of rape is arguably greater than they are for women. ${ }^{182}$ Rape against women often is perceived and stigmatized as deeply shameful, particularly in social or religious communities that seek to regulate women's sexual "purity" as a symbol of male honor. ${ }^{183}$ However, the rape of women does not subvert social constructions of women, which typically define women as dependent and in need of protection. In contrast, men who are raped have been sexually violated against their will, unable to protect themselves from the violence of other men. ${ }^{184}$ The experience of rape as victimization thus conflicts with the social construction of masculinity, which typically requires men to be strong, dominant, and heterosexual. As Alison argues, the sexual violation of men repositions them as powerless victims of male sexual power, challenging social definitions of masculinity. ${ }^{185}$

Some argue that masculine norms are heightened during wartime, ${ }^{186}$ when men are expected to take up arms and protect members of their family and social collective. This arguably heightens the shame and stigma of rape for male victims in war. A male victim who believes his victimization is incompatible with his masculinity, Lewis observes, may consider "his inability to protect himself and his community as a confidence-shattering personal failing." ${ }^{187}$ One male survivor of rape in Uganda, for example, describes the shame and social isolation he suffers after being raped. He was taken by rebels into the forest and

\footnotetext{
177 See Oosterhoff et al., supra note 58, at 70. See also DelZotto \& Jones, supra note 69.

178 Mezey \& King, supra note 61, at 87.

179 See Sivakumaran, supra note 2, at 266.

180 See id.

181 Onyango \& Hampanda, supra note 30, at 237.

182 See supra notes 168-74 and accompanying text.

183 DelZotto \& Jones, supra note 69. See also Bruce J. Malina, The New Testament World: Insights from Cultural Anthropology 48 (3d ed. 2001).

184 DelZotto \& Jones, supra note 69.

185 See Alison, supra note 16, at 81 .

186 See, e.g., Karen O. Dunivin, Military Culture: Change and Continuity, 20 Armed ForCES \& SOC'y 531, 533-35 (1994).

187 Lewis, supra note 38 , at 8.
} 
gang raped eleven times one night, along with other male prisoners. ${ }^{188}$ Despite medical treatment, he still bleeds when he walks. He refuses to tell his brother about the rapes, even when his brother asks what is the matter, because "I fear he will say: 'Now, my brother is not a man.' "189

Second, sexual violence against male bodies also functions as a gendered means to attack the larger collective that the particular victim (male or female) represents, such as an ethnic, religious, or political group. ${ }^{190}$ As Charli Carpenter explains, rape during war functions to "invert gendered constructions of protector/protected roles, with the aim of terrorizing entire societies." ${ }^{191}$ A report of sexual violence in eastern Democratic Republic of Congo states that the use of sexual violence to defeat a community is "the ultimate display of power and dominance ... used by the opposing force to signify the weakness and inadequacy of the men in the targeted social grouping or community. These men absorb this message, perceiving their inability to protect women against assault as their own final humiliation in the war." 192

Male and female bodies are both used during war by competing groups to construct competing masculinities. ${ }^{193}$ During the 1971 Bengali war and the conflict in former Yugoslavia, narratives about rape, and the use of rape by certain groups, were used by competing collectives to construct conceptions of national identity during conflict. ${ }^{194}$ The sexual violation of one group of women symbolically accomplishes the violation of the enemy, constructing the members of the perpetrators' group as masculine and the members of the enemy group as feminine. ${ }^{195}$ The sexual violation of men, as discussed above, similarly functions as a gendered means of dominance employed by one group or collective over another.

Third, the rape of men, like the rape of women, can constitute an act of genocide. Rape and sexualized violence against women in war is not merely an attack against one woman, nor the aberrant act of a single deviant. As feminist advocates have long argued, the sexual violation of women can constitute a weapon of genocide. This intersectional approach argues that women are raped not solely because they are women but because they are members of particular

188 Storr, supra note 32 (based upon interviews of Makerere University's Refugee Law Project and interviews with male victims of rape in Uganda).

189 Id.

190 Engle, supra note 71, at 788, 791.

191 Carpenter, supra note 48, at 96.

192 Susan Bartels et al., "Now, The World Is Without Me": An Investigation of Sexual Violence in Eastern Democratic Republic of Congo 5 (2010).

193 See Valorie K. Vojdik, Masculinities, Feminism, and the Turkish Headscarf Ban: Revisiting Şahin v. Turkey, in Masculinities and the Law: A Multidimensional Approach, supra note 141, at 270, 271; Yakin Ertürk, Towards a Post-Patriarchal Gender Order: Confronting the Universality and the Particularity of Violence Against Women, 46 SocIOLOGISK FORSKNING 61, 63-64 (2009) (discussing use of violence against women in Afghanistan as example of competing masculinities, Afghan Taliban and US military).

194 See_arkov, supra note 22, at 70-71. See also Alison, supra note 16, at 81.

195 Erin E. Welsh, Establishing Difference in Genocide: The Feminization of the 'Other' \& Masculinization of the Génocidaire 17 (Working Paper, 2012), available at http://citation .allacademic.com/meta/p_mla_apa_research_citation/5/4/4/4/2/p544422_index.html. 
ethnic groups. ${ }^{196}$ The rape of a woman by an enemy-combatant during armed conflict constitutes the actual and symbolic degradation of her community. Rape masculinizes the perpetrators, who physically and sexually violate and dominate the woman and, symbolically, her community. ${ }^{197}$ At the same time, rape emasculates the men in the women's community, who have failed to protect the women of their group or their community-both fundamental aspects of masculine identity. ${ }^{198}$

Like mass rape of women in the Congo or the former Yugoslavia, sexual violence against men actually and symbolically represents (and accomplishes) the destruction of the "other" group. Like the body of a woman who is raped by the group, the body of the male victim functions as the corporeal embodiment of the enemy, whether it be an ethnic or religious group, the state or nation, or some other collective identity. ${ }^{199}$ The sexual violation of men, then, represents the vanquishment of the collective itself. ${ }^{200}$ At the same time, it constructs the perpetrator as über-masculine and his group as dominant.

Fourth, sexual violence against men, like mass or gang rape of women in wartime, also functions as a tool of warfare against the enemy, used to terrorize and displace the enemy population. Numerous experts have reported on the use of sexual violence as spectacle, in which troops publicly raped and sexually violated women to instill fear and terror among civilians and empower the perpetrators. ${ }^{201}$ The gang rapes functioned to terrorize entire communities. In her study of gang rape of women during the conflict in Eastern Congo, Maedl reports that most of the gang rapes included multiple victims who were simultaneously raped, as well as beaten, killed, or abducted. ${ }^{202}$ In the majority of cases, the rapes occurred in view of others, including those who were forced to watch, such as the victims' husbands and children. ${ }^{203}$ In two instances, female victims were forced to sexually abuse others. ${ }^{204}$ After a gang rape of a woman in the Congo, militiamen deliberately mutilated her genitals before sending her back to her village. ${ }^{205}$ During the Rwandan genocide, bodies of victims were

\footnotetext{
196 Michele Lent Hirsch, Conflict Profiles: Bosnia, Women Under Siege (Feb. 8, 2012), http://www.womenundersiegeproject.org/conflicts.

197 Welsh, supra note 195.

198 DelZotto \& Jones, supra note 69.

199 Sivakumaran, supra note 1 , at 268.

200 Id. See also Alison, supra note 16, at 86 (explaining that the castration and forced rape and sexual performance by male prisoners "illustrates how male to male sexual violence is both gendered and ethnicised, acting to feminise victims and their homosexualised ethnonationality whilst masculinising perpetrators and their heterosexualised ethno-nationality").

201 See DelZotto \& Jones, supra note 69.

202 Maedl, supra note 161, at 143.

203 Id. (" 68.2 percent of the victims reported that others saw how they were raped, and 22.7 percent stated that others were forced to watch them being raped. In 13.6 percent of the cases the victim's husband had to watch; for another 13.6 percent, the victim's children had to watch").

204 Id. at 144.

205 Jim Bliss, The Limits of Empathy, QuiEt RoAD (Dec. 6, 2006), http://numero57.net /2006/12/06/the-limits-of-empathy/.
} 
mercilessly "left spread-eagled . . . as a reminder of the brutality and power of the genocide's perpetrators." 206

Public genital and sexual violence against men serves similar purposes. As the Special Court for Sierra Leone found, the RUF troops "reign of terror" involved sexual violence against both men and women in communities along with other forms of violence, including the amputation of limbs of men and boys. ${ }^{207}$ Similarly the ICTY documented instances of war crimes committed against particular communities in which both men and women were sexually violated and tortured. Male abductees have been forced to rape female abductees; male family members forced to have sexual intercourse with other family members, both and female. ${ }^{208}$ In each of these cases, military troops not only sexually violated women, but also men, using both sexual violence and other forms of torture against particular communities. While feminist scholars have focused on the female victims of these public campaigns of terror, men have also been targeted. The public rape, torture, or killing of men sends a message to the community that the enemy has destroyed those who are expected to protect the community, increasing the fear and vulnerability of the community.

Finally, sexual violence and rape of men often serves as a means of punishment that is used by armed groups to punish those men who refuse to join a militia or participate in killing. In Rwanda, for example, Hutu male combatants sexually assaulted other Hutu men who would not join in the killing. ${ }^{209}$ Some scholars, such as Carpenter, broadly define sexual violence against men to include forced recruitment of men and boys and sex-selective massacres of men and boys in communities belonging to the enemy. In these cases, violence is deployed against men and boys as a means of recruiting fighters and eliminating the enemy's ability to deploy troops.

Focusing on sexual violence against men through the lens of masculinities theory, then, illuminates the ways in which masculine power is constructed within groups of men and institutions such as the military, where sexualized violence is often used as a means to prove one's masculinity. The target of such violence, however, can be either male or female. As a gendered tool of war, sexual violence against men serves similar purposes as sexual violence against women. Both construct and enforce masculine power and domination.

\section{Future Directions: Situating Wartime Sexual Violence Against Men Within a Continuum of Violence Used to Construct Masculinities Throughout Society}

The sexualized violation and humiliation of men during war is a gendered social practice that is not unique to armed conflict. Rather, the use of sexual-

206 The Men Who Killed Me: Rwandan Survivors of Sexual Violence 17 (AnneMarie de Brouwer \& Sandra Ka Hon Chu eds., 2009).

207 See Prosecutor v. Sesay, Case No. SCSL-04-15-T, Judgment, It 1600 (Special Ct. for Sierra Leone Mar. 2, 2009).

208 See DelZotto \& Jones, supra note 69.

209 Buss, supra note 14, at 159 (discussing research revealing sexual assault of Hutu men by other Hutus; sexual assault used to humiliate and shame men who would not join killing). 
ized violence against particular groups of men is part of a continuum of regulatory social practices that construct and empower particular, hegemonic masculinities within social institutions. In the United States, for example, violence against men and boys occurs in many social institutions. From bullying in school, to workplace sexual harassment, to sexualized violence within the military, sexualized violence against men functions to regulate men as masculine and heterosexual. Like rape of men during war, sexual or gender violence against men is largely hidden from view, often silenced by the shaming of its male victims and normalized within society and the law. ${ }^{210}$

Bullying in US schools, for example, targets boys more than girls, and serves to enforce hegemonic notions of masculinity. ${ }^{211}$ Schools historically have ignored bullying, serving to render this type of gender violence against boys invisible. As Michael Higdon explains, bullying is highly gendered conduct, used as a means to punish boys and LGBTQ youth who do not conform to gender expectations. ${ }^{212}$ Ironically, boys who bully are often highly regarded by their peers, described as "physically strong, aggressive, dominating, and impulsive," highly prized masculine qualities. ${ }^{213}$ This makes it difficult for victims to report bullies and, by equating masculinity with violence, normalizes violence against gender nonconforming boys. ${ }^{214}$ Further, bullying of boys who do not conform to social expectations of masculinity is enforced by masculine norms rooted in homophobia, which Kimmel explains "is more than the irrational fear of gay men, more than the fear that we might be perceived as gay," it is a fear that other men will recognize that men are not as masculine as they pretend. ${ }^{215}$ As Ann McGinley explains, this fear of being labeled homosexual compels men to enact exaggerated masculine behaviors, such as bullying, to establish their own manhood, while simultaneously preventing boys and men from standing up for other men who are being sexually harassed or bullied. ${ }^{216}$ Like the silence surrounding male rape in war, the silence surrounding bullying in schools serves to normalize gendered violence against boys.

As with male-on-male wartime rape, male-on-male rape in US prisons is also largely ignored by society, as Bennett Capers argues in Real Rape Too. ${ }^{217}$ Capers notes that often victims fear being perceived as "weak, homosexual, or both" by reporting the rape. ${ }^{218}$ Like the rape of men in war, rape of men in prison is not about sexual desire, but rather power and male dominance. According to Capers, "most perpetrators of prison rape identify as heterosexual, engaged in heterosexual sex prior to prison, and return to heterosexual sex after

\footnotetext{
210 See Sivakumaran, supra note 2, at 262.

211 Michael J. Higdon, To Lynch a Child: Bullying and Gender Nonconformity in Our Nation's Schools, 86 IND. L.J. 827, 837 (2011).

212 Id. at 838 .

213 Id.

214 Id.

215 Kimmel, supra note 19, at 233.

216 See Ann C. McGinley, Creating Masculine Identities: Bullying and Harassment “Because of Sex”, 79 U. Colo. L. Rev 1151, 1164, 1179 (2008).

217 Capers, supra note 13, at 1261. Capers notes that such rape has even permeated mainstream popular entertainment, citing HBO's $O z$ as a television program that has incorporated male-on-male rape into the pathos of its entertainment. $I d$. at 1262 n.19.

218 Id. at 1266.
} 
prison. ${ }^{219}$ Like male victims of wartime rape, male prisoners face similar fears of stigmatization, shame, and of being incorrectly labeled as homosexual. ${ }^{220}$ Like wartime rape, prison rape has not been aggressively prosecuted. Even when rape is reported, "[p]rosecutors, faced with limited resources, rarely devote those resources to prosecuting prison violence."221 Even though the victim did not consensually engage in homosexual activity, the mere fact that he did, under whatever circumstances, is feared to impugn him as a homosexual.

These forms of masculinized violence toward men have been largely hidden in our society, often enforced by the shame and stigmatization that male victims suffer as a result of social scripts that value dominance and heterosexualized power in men. As more attention is focused on male victims of rape and sexual violence in war and other contexts, it is important to consider the gendered nature of such violence, as well as the ways in which masculinity intersects with race, ethnicity, sexual orientation, religion, and disability. In the future, reframing male-on-male violence needs to take into account the interlocking systems of gender, race, ethnicities, sexual orientation, and other systems that construct difference.

Masculinities theory is an extremely useful tool to illuminate the multidimensional nature of violence against both men and women in society. Feminists have done an outstanding job of making violence against women visible and locating violence as a means of male domination. It is now time to similarly illuminate gendered violence against male bodies-just as feminists have explored the violence against women that has been hidden from view, it is essential that we explore the myriad forms of violence against male bodies that remains largely invisible and thereby that function to normalize violence against men and boys. By broadening the framework to explore the gendered nature of violence against men, we not only recognize that gender-based violence harms both men and women, but we enrich our understanding of the gendered nature of violence and its relationship in preserving the dominance of particular groups of men in our society.

\section{CONCLUSION}

The wartime sexual violation of all bodies, male or female, is a crime against humanity that international law must punish and prevent. Though prevalent, sexual violence against men in war has remained invisible, its victims shamed and stigmatized as somehow less "masculine" than their perpetrators, or considered less deserving of protection because of their racial, ethnic, religious, or "other" status. It is also invisible because it has been normalized under the law, more often treated as "torture" of military combatants or detainees, a "natural" consequence of war in which men are typically the warriors, rather than conceptualized as a form of gendered violence.

It is time that we recognize the interrelatedness of sexual violence against women and men during war. Like sexual violence against women in war, sexual violence against men is about masculine dominance and power, a gendered

\footnotetext{
219 Id. at 1268.

220 Id.

221 Id. at 1270.
} 
social practice that constructs and enforces masculinity as heterosexual, dominant, and often violent. The male body, like the female body, is used as a symbol for the larger collective, particularly in times of conflict. Like rape of women, rape of men is a weapon of war, deployed as a means to assert the power of other collectivities, including ethnic, racial, local, and national groups vying for power.

Rape and sexual violence against men is not an aberration unique to war, but rather is part of a larger social and gender system that constructs male bodies as masculine, heterosexual, and dominant. It is one part of a continuum of violence against men that occurs throughout a range of social institutions that serves to empower particular groups of men as masculine and dominant. By illuminating masculinized violence against men, feminists can deepen their analysis of gender-based violence, exploring the relationship between violence against both men and women within a dominance framework. Masculinities theory helps enrich our understanding of gendered violence, revealing the ways in which the invisibility of violence against men serves to reinforce the construction of certain male bodies as masculine and dominant, in both war and in peace. 